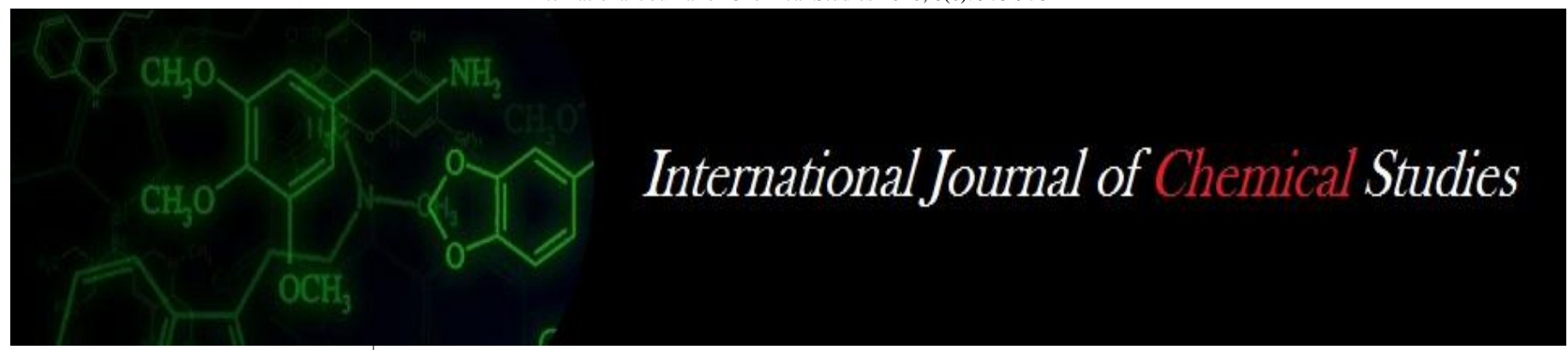

P-ISSN: 2349-8528

E-ISSN: 2321-4902

www.chemijournal.com

IJCS 2020; 8(6): 973-978

(C) 2020 IJCS

Received: 09-09-2020

Accepted: 22-10-2020

\section{SG Ninawe}

M.Sc. Student, Shri Shivaji

College of Agriculture, Amravati,

Maharashtra, India

PP Baviskar

Ph.D. Scholar, Department of

Agricultural Economics,

VNMKV, Parbhani,

Maharashtra, India

UP Gaware

Ph.D. Scholar, Department of Agricultural Economics, Dr. RPCAU, Pusa, Samastipur,

Bihar, India

\section{SD Wankhede}

Ph.D. Scholar, Department of Agricultural Economics, Dr. PDKV, Akola, Maharashtra, India

\section{KD Parvekar}

M.Sc. Student, Agricultural Economics and Statistic Section College of Agriculture, Nagpur, Maharashtra, India
Corresponding Author: SG Ninawe

M.Sc. Student, Shri Shivaji

College of Agriculture, Amravati, Maharashtra, India

\section{Decomposition analysis and acreage response of soybean in Amravati division}

\section{SG Ninawe, PP Baviskar, UP Gaware, SD Wankhede and KD Parvekar}

DOI: https://doi.org/10.22271/chemi.2020.v8.i6n.10892

\begin{abstract}
The present study entitled "Decomposition analysis and Acreage Response of Soybean in Amravati Division" was undertaken to study the growth rate and instability of area, production and productivity, decomposition of output growth, acreage response and price elasticity of selected crop i.e. Soybean in Amravati division and data pertained for the year 1988-89 to 2017-18 for the districts viz., Buldhana, Akola, Amravati, Yavatmal and Amravati Division as a whole. The study was based on time series secondary data on area, production, productivity, farm harvest prices, rainfall and other relevant data of selected crops were collected from the various Government publications.

The study revealed that the Compound growth rate for area and production under soybean was recorded high during period I in all the districts. During period II, the production of soybean registered mostly high growth rates in all the districts. During period III, the compound growth rate for area, production and productivity under soybean was found mostly decreased compare to period I and II of Amravati division of Maharashtra for the study period. The instability in the area, production and productivity of soybean was observed in almost all districts in the Amravati division. It may be because the crop largely depends on vagaries of nature which causes heavy losses. The Percent contribution of area effect was more responsible for soybean production in all the districts in all periods except period III. Therefore it is necessary to increase the sustainable soybean production in state and to take up productivity enhancing measures in soybean crop like varietal improvement, appropriate technologies. The lagged acreage variable was found significant in all the districts of Amravati Division mostly with one percent level of significance. The current year acreage was less influenced by farm harvest prices of soybean in all the districts. One year lagged yield had some impact to area allocation of Soybean in all the districts of Amravati division. Most of the long run price elasticities were greater than short run elasticities in soybean indicating that farmers were relatively market oriented in their decisions in long run than in short run.
\end{abstract}

Keywords: Acreage response, decomposition, growth rate, soybean

\section{Introduction}

Soybean (Glycine max) is expected to have originated in eastern Asia or China. Soybean is an important source of high quality but inexpensive protein and oil. It has an average protein content of $40 \%$ and oil content of $18 \%-20 \%$ Soybean protein has great potential as a major source of dietary protein. A byproduct from the oil production (Soybean cake) is used as a high protein feed in many countries. Soybean also improves soil fertility by adding nitrogen from the atmosphere. It has emerged as an important commercial crop in many countries. About $82-85 \%$ of the global Soybean production is crushed for oil and meal, while rest is consumed either in the form of 'bean' itself or for value added Soybean snack foods. The bulk of the crop is solvent extracted for vegetable oil and defatted Soy meal which is used for animal feed. The extracted Soy oil is one of the major sources of edible oil in the world. Soy oil remnant after oil extraction is rich source of protein for livestock. In 2009 Soybeans represented $53 \%$ of world oilseed production. In India, Soybean is a kharif crop. Its sowing begins by end of June with the arrival of southwest monsoon. The crop is ready for harvest by the end of September.

India is fifth largest producer of Soybean in the world and has been adding area under Soybean sowing since 2000. Production and productivity levels went up in past few years, but the country is still far behind China's productivity levels of $2,500 \mathrm{~kg} / \mathrm{hectare}$. The Soybean production in India is approximately 13158.73 million tonnes in 2016-17. 
Maharashtra (45.87 lakh tonnes) are the two major states and currently contribute more than 85 per cent to the total area and production of Soybean in India. It is seen that Madhya Pradesh was the highest producing state contributes 45 per cent to the total area under production of Soybean. It is followed by Maharashtra which occupies around one third area under Soybean and contributes 40 per cent to the total Soybean production. Soybean was grown mainly in the Vidarbha (Amravati and Nagpur Division) and Marathwada (Latur and Aurangabad) regions of Maharashtra. Amravati district was highest share in area under Soybean followed by Buldhana and Nagpur.

In India, area under Soybean was 11183.40(000 ha) with production of 13158.73 (000 tonnes) and productivity of 1177 $\mathrm{kg} / \mathrm{ha}$ in 2016-17, In Maharashtra it constitute 38.41 (lakh/ha) area with production of 45.87 (lakh/tonnes) and productivity of $1194 \mathrm{~kg} / \mathrm{ha}$ in 2016-17 In Amravati division area under Soybean was 14983 (00 ha) with production of 22212 (00 tonnes) and productivity of $1482 \mathrm{~kg} / \mathrm{ha}$ in 2016-17.

\section{Methodology}

The study has been undertaken to examine the various price and non-price factors for their roles in cultivators decision making about cropping pattern. The study further attempts to assess the direction and magnitudes of influences of contributory factors and also find out extent of deviation from planned acreage while making ultimate acreage allocation. The statistical tools and techniques employed in this study are also highlighted.

\section{Study area}

The study was confined to five districts of Amravati revenue division of Maharashtra state, namely Amravati, Akola, Buldhana, Yavatmal, Washim. The five districts constituted more or less in the middle of peninsular India and formed to be a part of Deccan plateau, named as Western Vidarbha region.

\section{Selection of period}

Based on the objective of the study, for the analysis of growth rate, instability, acreage response, decomposition, Short run and long run elasticity for the selected crops, the period was divided into breakup of 10 years and overall as shown below.

Period I - 1988-89 to $1997-98$

Period II - 1998-99 to 2007-08

Period III - 2008-09 to 2017-18

Overall period - $1988-89$ to $2017-18$

\section{Nature and source of data}

Data used for the present study was collected from various published sources. Time series secondary data on the area, production and productivity of selected crops, rainfall, farm harvest price and other data were obtained from various published sources.

1. Socio-economic review and district abstract of Maharashtra

2. Agricultural situation in India

3. Season and crop report Government of Maharashtra State

4. Area and Production of Principal Crops in Maharashtra.

\section{Analytical techniques employed for analyzing the data}

The present study was based on time series secondary data of selected crop i.e., Soybean in Amravati division. The study was conducted on the following aspects

\section{Growth rate analysis}

The compound growth rate of area, production and yield for soybean was estimated for three sub periods.

The district-wise compound growth rates was estimated to study the growth. It was estimated with the following exponential model.

$\mathrm{Y}=a b^{\mathrm{t}}$

$\log \mathrm{Y}=\log \mathrm{a}+\mathrm{t} \log \mathrm{b}$

$\mathrm{CGR}=($ Antilog $(\log b)-1) \times 100$

Where,

CGR $=$ Compound growth rate

$\mathrm{t}=$ time period in year

$\mathrm{y}=$ area/ production / productivity

$\mathrm{a} \& \mathrm{~b}=$ Regression parameters

\section{Instability Analysis}

To measure the instability in area, production and productivity, an index of instability was used as a measure of variability.

The coefficient of variation (CV) was calculated by the formula

$$
\mathrm{CV}(\%)=\frac{\text { Standard deviation }}{\text { Mean }} \times 100
$$

The simple coefficient of variation (CV) often contains the trend component and thus overestimates the level of instability in time series data characterized by long-term trends. To overcome this problems, we used the instability index (II) given by Coppock's instability index of variation. Coppock's instability index is a close approximation of the average year to year per cent variation adjusted for trend.

The algebraic form of equation is -

$\mathrm{CII}=[($ Antilog $\sqrt{ } \mathrm{V} \log -1 \times 100)]$

$\mathrm{V} \log =\sum \frac{\left[\log \frac{X_{t}+1}{X_{t}}-m\right]^{2}}{N-1}$

Where,

$\mathrm{X}_{\mathrm{t}}=$ Area/ production/ productivity in the year ' $\mathrm{t}$ '

$\mathrm{N}=$ Number of year

$\mathrm{m}=$ Arithmetic mean of difference

$\mathrm{V} \log =$ Logarithmic variation of the series

\section{Decomposition of output growth}

To measure the relative contribution of area, yield to the total output change for the soybean crop, Minhas (1964). The decomposition analysis model as given below was used. Sharma (1977) redeveloped the model and several research workers (Kalamkar et al., 2002) ${ }^{[3]}$ used this model and studied growth performance of crops on state. The method states that $\mathrm{A}_{0}, \mathrm{P}_{0}$ and $\mathrm{Y}_{0}$ respectively area, production and productivity in base year and $A_{n}, P_{n}$ and $Y_{n}$ are values of the respective variable in $\mathrm{n}^{\text {th }}$ year item.

Po $=$ Ao $x$ Yo and

$\mathrm{Pn}=\mathrm{A}_{\mathrm{n}} \times \mathrm{Y}_{\mathrm{n}}$

Where, 
Ao and $A_{n}$ represent the area and $Y_{0}$ and $Y_{n}$ represents the yield in the base year and $n^{\text {th }}$ year respectively.

$\mathrm{P}_{\mathrm{n}}-\mathrm{Po}=\Delta \mathrm{P}$,

$\mathrm{A}_{\mathrm{n}}-\mathrm{Ao}=\Delta \mathrm{A}$

$\mathrm{Y}_{\mathrm{n}}-\mathrm{Yo}_{\mathrm{O}}=\Delta \mathrm{Y}$

From equation (1) and (2) we can write

$\mathrm{Po}+\Delta \mathrm{P}=(\mathrm{Ao}+\Delta \mathrm{A})(\mathrm{Yo}+\Delta \mathrm{Y})$

Hence,

$$
\mathrm{P}=\frac{\mathrm{A}_{0} \Delta \mathrm{Y}}{\Delta \mathrm{P}} \times 100+\frac{\mathrm{Y}_{0} \Delta \mathrm{A}}{\Delta \mathrm{P}} \times 100+\frac{\Delta \mathrm{Y} \Delta \mathrm{A}}{\Delta \mathrm{P}} \times 10
$$

Production $=$ Yield effect + area effect + interaction effect Thus, the total change in production can be decomposed into three components viz. yield effect, area effect and the interaction effect due to change in yield and area.

\section{Acreage response analysis}

The model which generally used in supply response analysis based on time series data has been used adaptive expectations or Distributed Lagged model. In the present study the Regression model of the Nerlovian lagged adjustment model (1958) was used. The acreage response means the change in acreage with the unit change in the variables affecting on during the period of study.

At $a=a+b_{1} A_{t-1}+b_{2} F_{t-1}+b_{3} Y_{t-1}+b_{4} W_{t}+b_{5} P_{R}+b_{6} Y_{R}$

Where,

$\mathrm{a}=$ Area

$A_{t}=$ Area under crop at time 't' ('00' ha)

$A_{t-1}=$ One year lagged area under the crop ( 00 ' ha)

$\mathrm{FHP}_{\mathrm{t}-1}=$ Lagged year farm harvest price of the crop $(\mathrm{kg} / \mathrm{ha})$

$\mathrm{Y}_{\mathrm{t}-1}=$ One year lagged yield

$\mathrm{W}_{\mathrm{t}}=$ Weather variable as rainfall data per year.

$\mathrm{P}_{\mathrm{R}}=$ Price risk (coefficient of variation of last three years)
$Y_{R}=$ Yield Risk (coefficient of variation of last three years)

$b_{1} \ldots b_{6}=$ Parameters of multiple linear regression

The two models viz., Linear Regression Model and CobbDouglas Model were tested and out of these two Models finally Linear Regression Model was selected on the basis of Number of significant variables, desired signs of estimated regression coefficient and highest $\mathrm{R}^{2}$ values.

\section{Short run and long run elasticity}

The elasticity's of variables show that the influence of unit change in variable on acreage decisions of crop. In the present study, variable elasticity's were estimated for short run as well as for long run period.

Moreover, the short run and long run elasticity were estimated as -

$\begin{aligned} & \text { Short run } \\ & \text { Elasticity }(\mathrm{SRE})\end{aligned}=$ Regression coefficient of price $\mathrm{x} \frac{\text { Mean of price }}{\text { Mean of area }}$

Long run elasticity $(\mathrm{LRE})=\frac{\mathrm{SRE}}{\text { Coefficient of area adjustment }(\mathrm{r})}$

Where,

$r=1-($ coefficient of lagged area)

\section{Results and Discussion \\ Growth performance of soybean}

The growth performance of soybean pertaining to two periods and overall was presented in the Table 1, which revealed that due to introduction of soybean in the region during period I, the growth rates in area and production was recorded very high in all districts of Amravati division and Amravati division as a whole.

The highest increasing trend in area, production was recorded in Buldhana districti.e.118.02 per cent and 122.77 per cent per annum respectively while in case of productivity Yavatmal district is highest with 11.23 per cent per annum.

Table 1: District wise compound growth rates for soybean

\begin{tabular}{|c|c|c|c|c|c|c|}
\hline Particulars & & Buldhana & Akola & Amravati & Yavatmal & Amravati Division \\
\hline \multirow{3}{*}{ Period I } & Area & $118.02^{* * *}$ & $34.95^{* * *}$ & $23.91^{* * *}$ & $60.27^{* * *}$ & $32.58^{* * *}$ \\
\cline { 2 - 7 } & Production & $122.77^{* * *}$ & $39.62^{* * *}$ & $32.77^{* * *}$ & $78.06^{* * *}$ & $41.61^{* * *}$ \\
\cline { 2 - 7 } & Yield & $7.29^{*}$ & -0.35 & 7.1 & $11.23^{* * *}$ & $6.20^{* *}$ \\
\hline \multirow{3}{*}{ Period II } & Area & $25.12^{* * *}$ & $22.17^{* * *}$ & $3.52^{* *}$ & $23.84^{* * *}$ & $14.91^{* * *}$ \\
\cline { 2 - 7 } & Production & $29.73^{* * *}$ & $22.80^{* * *}$ & $8.50^{* * *}$ & $20.77^{* * *}$ & $16.94^{* * *}$ \\
\cline { 2 - 7 } & Yield & 3.6 & 7.36 & 1.01 & -2.7 & 2.6 \\
\hline \multirow{3}{*}{ Period III } & Area & $7.30^{* * *}$ & $5.20^{* * *}$ & 0.53 & -0.11 & $3.37^{* * *}$ \\
\cline { 2 - 7 } & Production & 13.45 & 8.05 & 0.49 & 2.9 & 6.51 \\
\cline { 2 - 7 } & Yield & 3.29 & 2.3 & -0.04 & $2.20^{*}$ & 2.25 \\
\hline \multirow{2}{*}{ Overall Period } & Area & $30.19^{* * *}$ & $21.73^{* * *}$ & $10.07 * * *$ & $19.72^{* * *}$ & $15.70^{* * *}$ \\
\cline { 2 - 7 } & Production & $30.80^{* * *}$ & $20.98^{* * *}$ & $10.36^{* * *}$ & $18.63^{* * *}$ & $15.87^{* * *}$ \\
\cline { 2 - 7 } & yield & 0.75 & $3.00^{* *}$ & 0.12 & -0.9 & 0.93 \\
\hline
\end{tabular}

(Note: $* * *, * *$ and $*$ denotes significances at $1 \%, 5 \%$ and $10 \%$ level of significance)

The result in period III revealed that the positive trend in area, production, and productivity, in all the district of Amravati division and Amravati division as a whole except for the area and yield of Yavatmal and Amravati district respectively. Thus the results clearly indicate that production was increased in most of the districts of Amravati division and Amravati division as a whole completely due to area expansion under soybean crop during the study period (1986-2017).In whole
Amravati division, Buldhana district showed the highest increase in area and production.

\section{Instability in soybean}

In order to know the instability in area, production and yield of soybean, the fluctuation measured with the help of coefficient of variation as well as Coppock's index as a coefficient of instability. The results are presented in Table 2 
and discussed as under for the period with ten years breakage and for overall period also. Fluctuation in area, production and productivity due to the uncontrollable factors like climatic conditions can cause upward bias in coefficient of variation. In case of soybean as this crop was introduced in the year 1980's. The Table 2 reveals that during period I, coefficient of variation for the yield was less when compared to area and production. Amravati district recorded with the lowest degree of instability in area i.e. (CV) 59.31per cent, (CII) 6.74 per cent per annum. While in production Amravati district was recorded with the lowest $(\mathrm{CV}) 71.68$ per cent per annum. In case of yield, Amravati division as a whole was recorded with the lowest degree of instability i.e. (CV) 23.24 per cent per annum and (CII) 16.64 per cent per annum. The highest instability for area was found in Buldhana district i.e. (CV) 111.74 per cent and (CII) 53.47 per cent per annum. The highest instability for production was found in Yavatmal district i.e. (CV) 116.45 per cent per annum. The highest variability for yield was found in Yavatmal district i.e. (CV) 34.67 per cent per annum.

Table 2: District wise instability indices for soybean

\begin{tabular}{|c|c|c|c|c|c|c|c|c|c|}
\hline \multirow{2}{*}{ Name of District } & \multirow{2}{*}{ Particulars } & \multicolumn{2}{|c|}{ Period I } & \multicolumn{2}{|c|}{ Period II } & \multicolumn{2}{|c|}{ Period III } & \multicolumn{2}{|c|}{ Overall } \\
\hline & & $\mathrm{CV}$ & CII & $\mathbf{C V}$ & CII & $\mathbf{C V}$ & CII & $\mathbf{C V}$ & CII \\
\hline \multirow{3}{*}{ Buldhana } & Area & 111.740 & 53.47 & 58.14 & 16.39 & 22.01 & 6.3 & 95.63 & 83.01 \\
\hline & Production & 107.22 & 52.02 & 84.35 & 35.05 & 56.79 & 47.95 & 115.9 & 99.18 \\
\hline & Yield & 31.3 & 25.89 & 38.19 & 36.78 & 50.08 & 49.45 & 41.25 & 5.77 \\
\hline \multirow{3}{*}{ Akola } & Area & 93.03 & 48.81 & 51.65 & 23.36 & 18.68 & 10.64 & 92.09 & 86.47 \\
\hline & Production & 101.78 & 53.37 & 62.45 & 28.62 & 51.91 & 47.83 & 101.36 & 91.03 \\
\hline & Yield & 25.93 & 25.91 & 34.32 & 29.18 & 56.98 & 56.64 & 56.06 & 24.92 \\
\hline \multirow{3}{*}{ Amravati } & Area & 59.31 & 6.74 & 21.48 & 17.87 & 11.81 & 11.71 & 62.83 & 58.08 \\
\hline & Production & 71.68 & 22.73 & 56.31 & 49.26 & 47.97 & 47.95 & 79.04 & 64.12 \\
\hline & Yield & 27.34 & 21.56 & 36.42 & 36.32 & 52.21 & 52.21 & 41.29 & 0.93 \\
\hline \multirow{3}{*}{ Yavatmal } & Area & 109.82 & 17.17 & 65.27 & 15.03 & 15.06 & 15.06 & 84.15 & 76.27 \\
\hline & Production & 116.45 & 22.23 & 65.27 & 23.65 & 47.27 & 46.5 & 88.42 & 73.74 \\
\hline & Yield & 34.67 & 20.64 & 21.33 & 20.39 & 58.59 & 8.76 & 38.74 & 6.3 \\
\hline \multirow{3}{*}{ Amravati Division } & Area & 77.34 & 10.62 & 43.91 & 11.02 & 13.9 & 9.87 & 81.19 & 77.24 \\
\hline & Production & 87.41 & 22.22 & 61.9 & 24.59 & 48.77 & 45.89 & 93 & 83.18 \\
\hline & Yield & 23.24 & 16.64 & 26.09 & 24.98 & 53.1 & 52.78 & 40.31 & 7.4 \\
\hline
\end{tabular}

Instability in area and production was found to be decreased and in yield it was found to be increasing in period II for all districts except for Yavatmal district where instability in production was increased. Instability in production was found to be decreasing in all the district of Amravati division and Amravati division as a whole. CII was highest for area in Akola district i.e.23.36 per cent per annum and for production Amravati district was found highest CII i.e. 49.26 per cent per annum while for yield highest CII were found in Buldhana district of Amravati division i.e 36.78 per cent per annum.

During the overall period i.e. 30 years as a whole, The highest $\mathrm{CV}$ for area was found in Buldhana district and for production also i.e. 95.63 and 115.90 per cent per annum respectively.while in yield highest CV calculated in Akola district i.e 5.06 per cent per annum. On other hand Highest CII was recorded for area in Akola district i.e. 86.47 per cent per annum. And for production highest CII was recorded in Buldhana district i.e. 99.18 per cent per annum. While with respect to yield highest CII recorded in Akola district i.e 24.92 per cent per annum. Lowest CV were recorded with respect to area and production in Amravati district. While in yield Yavatmal district recorded as lowest CV i.e 38.74 per cent per annum. And lowest CII were recorded for area, production in Amravati district i.e. 58.08, 64.12, 0.93 per cent per annum respectively.

\section{Decomposition analysis of soybean}

The decomposition of soybean production in area, yield and interaction effect is presented in Table 3 and results demonstrate that per cent contribution of area, yield and their interaction for increasing production of cotton in Western Vidarbha (i.e. Amravati division) and overall also.

During period I, in all the districts of Amravati division area, yield and interaction effects were positive. In Amravati division as a whole area effect recorded was 46.47 per cent where yield effect was 4.91 per cent and interaction effect was 48.62 per cent. The lowest area effect was found in the Yavatmal district 33.23 per cent and highest area effect and lowest yield effect was found in Akola district and Buldhana district with 73.24 per cent and 0.20 per cent respectively. The highest yield effect found in Amravati division as a whole and the lowest interaction effect were found in Akola district i.e. 4.91 per cent and 23.57 per cent respectively. Thus over all area effect has played a driving force in the differential production of Soybean in Amravati Division during period $\mathrm{I}$.

Table 3: Percent contribution of area, yield and their interaction for increasing production of soybean

\begin{tabular}{|c|c|c|c|c|c|c|}
\hline Period & Particulars & Buldhana & Akola & Amravati & Yavatmal & Amravati Division \\
\hline Period I & Area Effect & 43.18 & 73.24 & 35.43 & 33.23 & 46.47 \\
\hline & Yield Effect & 0.20 & 3.19 & 9.22 & 1.16 & 4.91 \\
\hline & Interaction Effect & 56.63 & 23.57 & 55.36 & 65.62 & 48.62 \\
\hline Period II & Area Effect & 12.86 & 22.00 & 56.85 & 109.15 & 44.90 \\
\hline & Yield Effect & 12.21 & 7.89 & 26.45 & -1.60 & 14.83 \\
\hline & Interaction Effect & 74.93 & 70.11 & 16.7 & -7.55 & 40.27 \\
\hline Period III & Area Effect & 12.03 & 12.16 & -23.48 & -16.55 & 4.64 \\
\hline & Yield Effect & 52.48 & 67.33 & 160.42 & 142.79 & 86.62 \\
\hline & Interaction Effect & 35.49 & 20.50 & -36.94 & -26.24 & 8.73 \\
\hline
\end{tabular}




\begin{tabular}{|c|c|c|c|c|c|c|}
\hline Overall Period & Area Effect & 30.97 & 62.83 & 45.20 & 46.36 & 47.70 \\
\hline & Yield Effect & 0.02 & 0.32 & 3.17 & 0.21 & 0.80 \\
\hline & Interaction Effect & 69.01 & 36.85 & 51.64 & 53.43 & 51.49 \\
\hline
\end{tabular}

Domination of area effect on yield and interaction effect continues in period II, except for Buldhana and Akola district where interaction effect was higher than area effect. In Amravati division area effect, yield effect and interaction effect recorded were 44.90 per cent, 14.83 per cent and 40.27 per cent respectively. The highest area effect and the lowest yield, interaction effect were seen in Yavatmal district i.e. 109.15 cent, -1.6 per cent and -16.55 per cent respectively. Similarly, the lowest area effect and the highest yield and interaction effects were recorded in Buldhana, Amravati district i.e. 12.86 per cent, Amravati per cent and 26.45 and 74.93 per cent respectively. So, the result clearly indicated that in this period area effect has played a driving force in the differential production of Soybean in Amravati Division.

During period III area effect, yield effect, and interaction effect was calculated in whole Amravati division 4.64 per cent, 86.62 per cent, 8.73 per cent respectively. Highest area effect, yield effect, and interaction effect was recorded in district Buldhana and Amravati, i.e.12.03 per cent, 160.42 per cent, and 30.97 per cent respectively. Lowest area effect, yield effect interaction effect, were recorded in Amravati, Buldhana, district i.e. -23.48 per cent, 52.48 per cent, -36.94 per cent respectively. Domination of yield effect on area effect and interaction effect was shown.

During overall period, interaction effect has recorded domination over area and yield effect. In Amravati division area effect, yield effect and interaction effect were recorded 47.7 per cent, 0.80 per cent and 51.49 per cent respectively. Positive area effect, yield effect and interaction effect were recorded in all districts. The highest area effect were seen in Amravati division as a whole i.e. per cent, 47.7 per cent. And lowest area effect were found in Buldhana district i.e. 30.97 per cent so clearly observed that yield effect was not increased in proportion to area effect. The lowest yield effect and the highest interaction effect were found in Buldhana district i.e. 0.02 per cent and 69.01 per cent respectively.

\section{Acreage response of Soybean}

Acreage response functions were fitted to examine the effect of price and non price factors on farmer's decision in allocating the area soybean in Western Vidarbha (i.e. Amravati division). The results obtained are presented and discussed in this section. Table 4 present the district wise estimated hectareage response functions of Soybean grown in most of the part of the western Vidarbha zone of Maharashtra which act as a major source of dietary requirement crop to the farmers. Out of two, linear regression model and CobbDouglas model, on the basis of number of significant variables, desired signs of estimated regression coefficient and higher $\mathrm{R}^{2}$ values Linear model was selected with the price and non price variables. With a view of estimating the response of producers in terms of soybean area towards price and non price factors the actual area in the current year was expressed as a log-linear function of one year lagged area, one year lagged farm harvest prices, one year lagged yield, average annual rainfall, yield risk and price risk. The regression coefficient of these explanatory variables are presented in Table 4 revealed that the lagged area was found to be positively influential factors in the farmer's decision regarding area allocation to Soybean and found significant at 1 per cent level of significance in all districts of Amravati division.

Table 4: Coefficients for acreage response function of Soybean

\begin{tabular}{|c|c|c|c|c|c|c|}
\hline \multirow{2}{*}{ Particulars } & \multirow{2}{*}{ Variables } & \multicolumn{5}{c|}{ Coefficients } \\
\cline { 3 - 7 } & & Buldhana & Akola & Amravati & Yavatmal & Amravati Division \\
\cline { 2 - 7 } & Intercepts & -277.34 & -413.7 & -457.4 & -178.2 & -718.63 \\
\hline One year lagged area & $\mathrm{A}_{\mathrm{t}-1}$ & $1.01^{* * *}$ & $0.87^{* * *}$ & $1 * * *$ & $0.96^{* * *}$ & $0.96^{* * *}$ \\
\hline One year lagged farm harvest price & $\mathrm{FHP}_{\mathrm{t}-1}$ & 0.03 & 0.07 & -0.05 & -0.02 & -0.07 \\
\hline One year lagged yield & $\mathrm{Y}_{\mathrm{t}-1}$ & $0.28^{* * *}$ & $0.2 * *$ & $0.28^{*}$ & $0.41^{* *}$ & $0.31^{* * *}$ \\
\hline Annual rainfall & $\mathrm{W}_{\mathrm{t}}$ & 0.08 & 0.08 & 0.53 & -0.17 & -0.28 \\
\hline Yield risk & $\mathrm{Y}_{\mathrm{r}}$ & -0.21 & 4.67 & -2.3 & 1.37 & 2.1 \\
\hline Price risk & $\mathrm{P}_{\mathrm{r}}$ & -1.01 & $16.69^{* * *}$ & -1.86 & 2.13 & 21.1 \\
\hline Coefficient of determination & $\mathrm{R}^{2}$ & 0.99 & 0.97 & 0.97 & 0.94 & 0.98 \\
\hline
\end{tabular}

(Note: $* * *, * * \& *$ denotes significant at $1 \%, 5 \% \& 10 \%$ level of significance)

The coefficients of farm harvest prices in all districts of Amravati division and Amravati division as a whole were negative except for Buldhana and Akola district it was positive. The coefficients of farm harvest prices of all districts of Amravati division i.e. $0.03,0.07,-0.05$ and -0.02 in Buldhana, Akola, Amravati and Yavatmal districts respectively. Whereas, coefficient of farm harvest price of Amravati division as a whole was positive and significant at 10 per cent level of significance, which implies that prices had shown negative impact in the increase on area of Soybean in the study period.

One year lagged yield was also included in the function which was shown positively significant in all the district of Amravati division, Buldhana district and Amravati division as a whole was found 1 per cent significant at significance level rather that Akola and Yavatmal district recorded 5 per cent significant at significance level and remaining Amravati district was found 10 per cent significant at significance level which showed one year lagged yield favourably influenced in area allocation of Soybean in all the districts of western Vidarbha zone of Maharashtra.

The annual rainfall was employed as a proxy for combating the weather influence on the Soybean hectareage allocation decisions. The coefficient of annual rainfall variable showed negative relationship in Yavatmal district and Amravati division as a whole and positive relation to Buldhana, Akola, Amravati district and statistically insignificant in all districts which showed annual rainfall favourably didn't influence the area allocation decision of the farmers.

The yield risk variable was incorporated in the model to gauge the impact of risk over the variation in the hectareage under Soybean. The coefficient of variable had a positive 
relationship in Akola, and Yavatmal districts and negative relationship in Buldhana and Amravati district and statistically insignificant in all districts of Amravati division which shows farmers are less risk bearers.

It was also recorded that regression coefficient of price risk variable or factors were negative in Buldhana and Amravati district rather that Akola, Yavatmal and Amravati division as a whole were positive and Akola district showed 1 per cent significant at significance level that testified to the farmers less risk aversion behaviour in Soybean production.

The value of $\mathrm{R}^{2}$ i.e. the coefficient of multiple determinations ranged from 0.94 to 0.98 for all the districts of Amravati Division. It was 0.99, 0.97, 0.94 and 0.94 found in Buldhana, Akola, Amravati and Yavatmal districts respectively, which indicates that variables included in the model explained most of the variations in area under Soybean in the study period.

\section{Short run and long run elasticity of Soybean}

The variations in the magnitude of short run and long run price elasticity factors between different districts of western Vidharba zone were evident from the Table 5. The short run and long run price elasticities of Soybean showed positive price responsiveness of farmers in all districts of Amravati Division and Amravati division as a whole.

The short run price elasticity for different districts are 0.03 , $0.02,-0.02$, and -0.01 for Buldhana, Akola, Amravati and Yavatmal districts respectively. The highest short run price elasticity was found in the Buldhana district i.e. 0.03 and lowest short run price elasticity was found in the Amravati district i.e. -0.02 .

Table 5: District wise Price Elasticity of Soybean in Western Vidarbha

\begin{tabular}{|c|c|c|c|}
\hline Sr. No & Name of Districts & SRE & LRE \\
\hline 1 & Buldhana & 0.03 & -1.94 \\
\hline 2 & Akola & 0.02 & 0.22 \\
\hline 3 & Amravati & -0.02 & 2.19 \\
\hline 4 & Yavatmal & -0.01 & -0.4 \\
\hline 5 & Amravati division & -0.01 & -0.27 \\
\hline
\end{tabular}

The long run elasticity for are Buldhana, Akola, Amravati and Yavatmal districts are $0.03,0.02,-0.02$, and -0.01 respectively. It is also recorded from the table that long run price elasticities are comparatively higher than the short run price elasticity indicated that the farmers were relatively market oriented in their decisions in the long run than in the short run in respect to the Soybean in the western Vidarbha region of the Maharashtra.

\section{Conclusion}

The study revealed that the Compound growth rate for area and production under soybean was recorded high during period I in all the districts. During period II, the production of soybean registered mostly high growth rates in all the districts. During period III, the compound growth rate for area, production and productivity under soybean was found mostly decreased compare to period I and II of Amravati division of Maharashtra for the study period. The instability in the area, production and productivity of soybean was observed in almost all districts in the Amravati division. It may be because the crop largely depends on vagaries of nature which causes heavy losses. The percent contribution of area effect was more responsible for soybean production in all the districts in all periods except period III. Therefore it is necessary to increase the sustainable soybean production in state and to take up productivity enhancing measures in soybean crop like varietal improvement, appropriate technologies. The lagged acreage variable was found significant in all the districts of Amravati Division mostly with one percent level of significance. The current year acreage was less influenced by farm harvest prices of soybean in all the districts. One year lagged yield had some impact to area allocation of soybean in all the districts of Amravati division. Most of the long run price elasticities were greater than short run elasticities in soybean indicating that farmers were relatively market oriented in their decisions in long run than in short run.

\section{References}

1. Agarwal PK, OP Singh. Growth and instability of Soybean production in Madhya Pradesh, India: a decomposition approach. Ann. of Agric. Bio. Res 2014;19(3):554-560.

2. Borkar P, VM Bodade, ER Patil. Growth and instability of Soybean in Vidarbha, Maharashtra. Green Farming 2010;1(6):649-650.

3. Kalamkar SS, Shende NV, Atkare VG. Course cereals and pulses production in India: Trends and decomposition analysis. Agric. Sit. in Indian 2002;59(1):581-587.

4. Mankawade KR, SS Thakare, DH Ulemale, SL Rathod. Decomposition analysis and acreage response of soybean. Agric. Update 2015;10(3):271-277.

5. Raghuvanshi RS, RM Sahu, Roshni Tiwari. Growth performance of Soybean in Malwa Plateau of Madhya Pradesh Bhartiya Krishi Anusandhan Patrika Year Volume 2008;23(3-4).

6. Shende NV, Thakare SS, Roundhal PS. Acreage responses and decomposition analysis of soybean in Western vidharbha. J Food Leg 2011;24(2):133-137. 